\title{
日本の世界文化遺産における森林の現状に関する考察
}

\section{A Study on the Existing Condition of the Forest Areas in the World Cultural Heritage Sites in Japan}

\author{
黒田 乃生* \\ Nobu KURODA
}

\begin{abstract}
The comprehensive protection of cultural and natural heritage has been an issue and has also been discussed by the World Heritage Committee. Through an analysis of the current situation of forests in the World Cultural Heritage Sites, the following points are clarified. In general, $74 \%$ of all properties and $77 \%$ of properties and buffer zones are covered with forests. Within the forest area, $36 \%$ of the forests are planted forests and $20 \%$ are national forests. Most of the forests have been under the influence of human activity, which has resulted in characteristic vegetation. A local-government level forest management plan that corresponds to the character of the forests and provides comprehensive protection to the cultural and natural elements is essential. Moreover, the evaluation process for cultural heritage should incorporate specific description of the vegetation as this will lead to an objective assessment and effective management plan.
\end{abstract}

Keywords: World Cultural Heritage, Forest, GIS

キーワード : 世界文化遺産, 森林, GIS

\section{1.はじめに}

\section{(1) 背景と目的}

日本は 1992 年にユネスコの「世界の文化遺産及び自然遺産の 保護に関する条約」を締結し, 現在 11 件の文化遺産と 3 件の自 然遺産が世界遺産一覧表に記載されている。世界遺産委員会では 自然環境への人間の働きかけの結果生み出された「自然と人間と

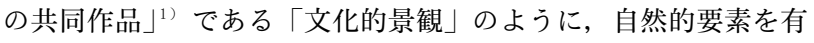
する文化遺産の保護が進められている。文化遺産における自然的 要素としては, 植物相や動物相, 地質や地形, 土袞などがあげら れるが，これらについては自然遺産保護と文化遺産保護の双方の 視点が欠かせないという指摘もある ${ }^{2)}$ 。しかし, 実際には文化遺 産はICOMOS, 自然遺産はIUCN が, 国内でも文化遺産は文化 庁, 自然遺産は環境省がそれぞれ評価と保護の措置を所管してお り，文化遺産における自然的な価值の保護が包括的な体系の下に 行なわれているとは言いがたい。

また, 日本では「紀伊山地の霊場と参詣道」における林業関係 者による抗議の落書きの例のように ${ }^{2)}$, 時間の経過や人為によっ て変化する森林のような自然的要素について, その役割と保護管 理の手法が明確になっていない面もあると考えられる。

以上の背景から, 本研究では自然的要素である森林を対象とし て, 日本における世界文化遺産の登録資産及びそのバッファーゾー ン（以下，本論に扔いて「世界文化遺産地域」という。）に打け る現状を把握し, 保護のありかたについて考察することを目的と する。「世界文化遺産地域」の森林については, ケーススタディ はあるが4)，すべての世界遺産を対象とした横断的な研究はない。 (2) 研究の方法

本研究ではまず, 日本政府が世界遺産委員会に提出した世界遺 産一覧表記載推萀書 ${ }^{5}$ （以下，本論において「世界遺産推鷹書」 という。）における森林の位置づけを把握した。次に, 既往研究 の成果と GISによって分析した植生データから，「世界文化遺産 地域」における森林の現況を明らかにした。最後に「世界文化遺
産地域」における自然公園と国有林の現状を把握した。以上の結 果から,「世界文化遺産地域」における森林の今後の保護の方向 性について考察した。

植生に関連するデー夕は環境省生物多様性セン夕ー運営の「生 物多様性情報システム」 $\rfloor^{6)}$, 国有林のデー夕は国土交通省の「国 土数值情報」7) を用いた。分析はArcGISを用い,「世界遺産推萀 書」 () $^{8}$ かスキャンした地図画像について基図の座標系 (平面直 角座標系) に従ってジオリファレンスを施した後, 当該地区（登 録資産及びバッファーゾーン) をトレースしてポリゴンデー夕を 作成した。なお，「生物多様性情報システム」及び「国土数值情 報」のデー夕は緯度経度座標系で作成されているため, 投影法変 換を施した後, オーバーレイ分析により植生の面積を算出した。 森林の面積については世界文化遺産 11 件を対象とし, 森林の位 置, 国有林の面積, 自然公園については森林の分布していない 「原爆ドーム」と「姫路城」を除く 9 件を対象とした。

\section{2.「世界遺産推薦書」にみる森林の位置づけ}

登録されている 11 件について,「世界遺産推萀書」から森林に 関する記載をまとめると表- 1 のとおりである。11 件中森林に 関する記述は 8 件でそのうち 6 件は宗教に関連するものである。

宗教に関連する記述として,「古都京都の文化財（京都市，宇 治市，大津市）」(以下「古都京都」）では賀茂別雷神社（上賀茂 神社）が後方や周囲の森林を含んでいることが特徵とされ，自然 的特性が歴史的環境に必要不可欠であると述べられている。また, 「撖島神社」では「瀰山を中心とする島全体をご神体とし，それ を遥か離れた場所から拝むことから信仰が始ま」ったとし，「自 然景観」の重要性については繰り返し述べられているが，森林に 関する具体的な記述はない。「古都奈良の文化財」（以下「古都奈 良」) では天然記念物に指定されている春日山原始林が世界遺産 を構成する登録資産となっており，「自然に対する原始的な信仰」 は「日本人の伝統的な自然観」と結びついているとしている。

"筑波大学大学院人間総合科学研究科 


\section{表－１「世界遺産推薦書」における森林に関する記述の有無}

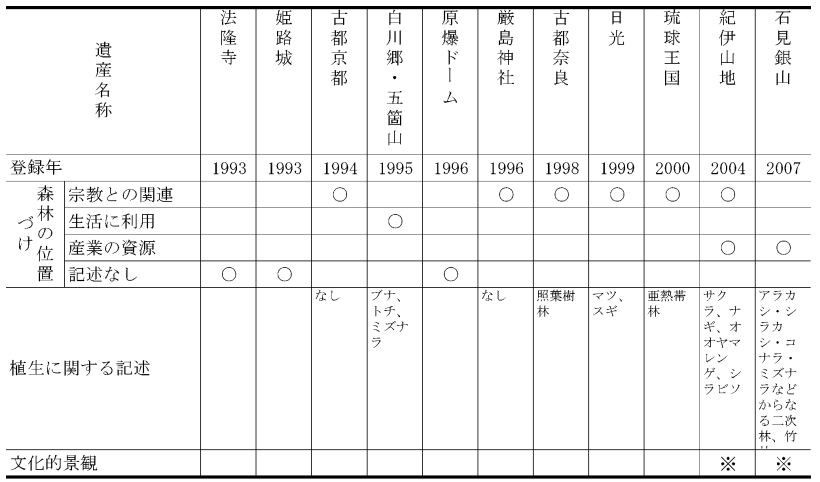

「日光の社寺」(以下「日光」) では，「山林地域」が「日本独特の 神道思想」と関連して, 自然と社殿が一体となった文化的景観を 形成しているとしている。「琉球王国のグスク及び関連遺産群」 (以下「琉球王国」) では斎場御獄について「亜熱帯林で覆われ, 様々な形をした岩塊の景観が，格式高い御獄の神々しい雾囲気を 醸成し」，また「既存樹木の中から外来種を間引くなど，御獄の 重要な要素である叢林の林叢復元にも配慮し, 荘厳な雾囲気の醸 成に努めている。」と述べられている。「紀伊山地の霊場と参詣道」 （以下「紀伊山地」）では天然記念物に指定されている2つの原始 林について, 那智原始林は「自然信仰と関連する」, 仏経獄原始 林は修験者の行場として樹木の伐採が禁止されてきた「自然林」 として取り上げられている。宗教に関連した森林は「日本人の自 然信仰」,「自然と宗教施設が一体となった景観」という言葉で抽 象的に語られている点が共通している。

生活に関連したものとしては「白川郷・五箇山の合掌造り集落」 (以下「白川郷・五箇山」) の和紙の原料の採取及び雪持林として の役割が記述されている。

産業に関連したものとしては,「紀伊山地」で「林業が基幹産 業になることによって都市化が阻まれ」た結果, 現在「深い森林 に打わわれている」という部分があげられる ${ }^{9)}$ 。また，「石見銀 山遺跡とその文化的景観」（以下「石見銀山」）では，銀の製錬の ための燃料確保の場であった現在の二次林と竹林が重要な遺産の 構成要素であること, 燃料の木炭を得るために樹木か政策的に管 理されていたことが説明されている。

そのほかバッファーゾーンの景観への森林の寄与としては「古 都京都」で風致地区, 歴史的風土特別保存地区についての言及が あるのみである。

具体的な樹種の記述は， 8 件中 4 件にすぎないが，文化的景観 として登録されている 2 件では, 他の遺産と異なり, 具体的な樹 種の記述も見られる。特に，「石見銀山」は付属資料として植生 図が揭載されている。

「世界遺産推薦書」は，世界遺産の登録に向けて戦略的に記述 されているため, これがすべての価值を網羅しているわけではな い。特に「姫路城」や「法隆寺」は国内では初期の登録にあたり, 「建造物」が中心の価值であるため森林の記述が少ないのは必然 ともいえる。しかし, 宗教的, 産業的な価值を持っているにもか かわらず, 森林に関する記述は, 個々の宗教建造物に関する時代 考証をも含めた詳細な記述に比べ少ないといわざるを得ない。

\section{3 .「世界文化遺産地域」における森林の現況}

\section{(1) 面積}

11 件の「世界文化遺産地域」における森林の面積と位置につ いて，GIS を用いて分析した ${ }^{10)}$ 。まず，土地利用を植生自然度か
ら「森林」, 「草原」,「農耕地」,「市街地その他」にまとめ, 面積 を算出した (表一 2 (1) ${ }^{11)}$ 。登録資産では約 2,400 ha $(74 \%)$, 登 録資産とバッファーゾーンをあわせた「世界文化遺産地域」全体 では約 25,000ha（77\%）が森林であり，全国の森林の面積の割 合 $67 \%$ に比へてて 1 割多くなっている。個々の森林の面積をみる 之登録資産は「古都京都」が約 800ha，「世界文化遺産地域」で は「紀伊山地」が約 9,700 ha と最も広い。また，森林面積の割 合で見ると，登録資産では 9 割近い「厳島神社」を筆頭に，「古 都京都」,「石見銀山」が 8 割を超えていて,「世界文化遺産地域」 では,「厳島神社」,「石見銀山」,「白川郷・五箇山」,「紀伊山地」 がいずれも 8 割を超えている。また，農耕地の割合が全国平均に 比べ少ないことも特徴である。

次に，森林に扔ける植林地の割合を見ると，「世界文化遺産地 域」では植林地が約 4 割, 植林地以外の森林が約 6 割である。登 録資産では植林地が多い「日光」と植林地以外の森林が多い「厳 島神社」，「琉球王国」，「古都奈良」，「石見銀山」に分かれた。 「世界文化遺産地域」では「日光」，「白川郷・五箇山」，「紀伊山 地」の植林地が 4 割を越えている。

\section{(2) 位置}

森林の位置は，「世界文化遺産地域」全体で見ると，遺産が都 市域とその周辺の森林の縁部に位置する「法隆寺」, 「古都京都」, 「古都奈良」と, 周辺も森林で覆われていて, そのなかに遺産が 位置する「白川郷・五箇山」，「日光」，「紀伊山地」，「石見銀山」， 遺産地区の森林が周辺の森林と接していないか又は僅かに接して いるのみの「厳島」「琉球王国」にわけることができる（図－1）。 文化遺産はいくつかの登録資産から構成されるが, 次にこれらの 資産とバッファーゾーン及び周辺の森林の配置の関係を分類し $た^{12}$ 。その結果, A. 森林が資産の価值の場合, B. 資産の位置に 森林がある，つまり，資産のほぼ全域が森林で構成されている場 合， C．資産の背後に広がる背景としての森林，D．点在する資 産を包み込む形，つまり資産の舞台としての森林，E．森林と隣 接しない場合, に分けることができた（表－3）。

9 件の世界文化遺産のうち, A は「古都奈良」の春日山原始林, 「嚴島神社」の彌山, 「紀伊山地」の那智原始林の 3 件 3 資産であ る。B は「琉球王国」の斎場御獄など 4 件 11 資産あった。また, $\mathrm{C}$ の後背林と接する登録資産は「石見銀山」,「白川郷・五箇山」 集落と「古都京都」,「紀伊山地」の社寺などである。Dの点在す る資産を包み込む森林には「紀伊山地」の吉野山などがあげられ る。9 件で 81 ある資産のうち，86\%の 70 資産が森林と接してい ることが明らかになった。

\section{(3) 植生}

全体で見ると寒帯・高山帯樹林以外のすべての植生区分を網羅 しており，特に「紀伊山地」は多様である（表－2 (3), 図－1）。 森林のある 9 件における主な群落は表－4 の通りである。

「法隆寺」,「古都京都」,「古都奈良」ではアカマツが多くなっ ている。「法隆寺」はアカマツのほかは植林地とクヌギーコナラ 群集となっておりいずれも人の手の入った森林であることがわか る。「古都京都」の東山ではアカマツを主体とした「風致施業」 が昭和初期から行なわれたが ${ }^{132} ， 1980$ 年代からのマツ枯れによっ て減少し ${ }^{14)}$, 現在はナラ枯れの被害がでている ${ }^{15)}$ 。また, 後背林 の常緑樹は, 高山寺, 鹿苑寺, 慈照寺にアラカシ群落が, 延暦寺 及び醍醐寺の一部にモミーシキミ群落が, 西芳寺, 清水寺, 醍醐 寺，宇治上神社にはサカキーコジイ群落が分布している。

「古都奈良」の登録資産である春日山原始林は約 $220 \mathrm{ha}$ のサ カキーコジイ群集となっているが，周辺はクヌギーコナラ，モチ ツッジーアカマツの二次林之植林地に囲まれており，その「孤立 性」が弱点とされている ${ }^{16)}$ 。春日山原始林は 9 世紀に伐採を禁止 されて以来, 春日大社の神域とされ, 秀吉時代の植林など部分的 
に人の手を加えた記録が残されているものの, 長い間人為的影響 をあまり受けることなく維持されてきた貴重な照葉樹林である ${ }^{17)} 。$ しかし, 植物群落レッドデータブックに掲載され, シカや移入植 物によるインパクト, 森林の種多様性の低下が指摘されている ${ }^{18)}$

「白川郷・五箇山」の五箇山ではブナーミズナラ群集の中にケ ヤキ群集, ヒメアオキーブナ群集, ヒメヤシャブシータニウツギ 群落が点在している。白川郷はチシマザサーブナ群団が分布して いるが, 白川郷の背景となっている森林はオニグルミ, クリなど 食用になる樹種が優先し, 合掌造り家屋に用いるマンサクも多く 見られること, 種の多様性が高いことが明らかになっている ${ }^{19)} 。$ また, 白川郷や五箇山の森林では多くのカヤバがあったが減少し
ていること，森林の利用が少なくなったことにより，景観が変化 していることが指摘されている ${ }^{200}$ 。五箇山では「古都京都」同様, ナラ枯れの被害が拡大している11。

「厳島神社」は 9 割がコバノミツバツツジーアカマツ群集であ る。「厳島」については 70 年以上にわたる植物及び植生に関する 調査研究の蓄積がある ${ }^{22)}$ 。1970 年代のマツ枯れの被害拡大に伴う 調査では, 常緑広葉樹林の要素を多くとどめた二次林であること など，本土と異なる特徵を持っことが明らかになった ${ }^{23)}$ 。現在の 植生は江戸時代の山火事から自然状態で回復したもので，登録資 産の彌山原始林にもブナ科, ツバキ科, クスノキ科などの照葉樹 が豊富に見られる ${ }^{24)}$

表－２「世界文化遺産地域」の(1)土地利用、(2)植林地、(3)植生帯

\begin{tabular}{|c|c|c|c|c|c|c|c|c|c|c|c|c|c|c|c|c|}
\hline \multirow{10}{*}{$\begin{array}{l}\text { (1) } \\
\text { 土 } \\
\text { 地 } \\
\text { 利 } \\
\text { 用 }\end{array}$} & & & $\begin{array}{l}\text { 法 } \\
\text { 隆 } \\
\text { 寺 }\end{array}$ & $\begin{array}{l}\text { 姫 } \\
\text { 路 } \\
\text { 城 }\end{array}$ & $\begin{array}{l}\text { 古 } \\
\text { 都 } \\
\text { 京 } \\
\text { 都 }\end{array}$ & $\begin{array}{l}\text { 吾川 } \\
\text { 箩川郡 } \\
\text { 山. }\end{array}$ & $\begin{array}{l}\text { 原 } \\
\text { 㩧 } \\
\text { । } \\
\text { ム }\end{array}$ & $\begin{array}{l}\text { 厳 } \\
\text { 島 } \\
\text { 神 } \\
\text { 社 }\end{array}$ & $\begin{array}{l}\text { 古 } \\
\text { 都 } \\
\text { 奈 } \\
\text { 良 }\end{array}$ & $\begin{array}{l}\text { 日 } \\
\text { 光 }\end{array}$ & $\begin{array}{l}\text { 琉 } \\
\text { 球 } \\
\text { 王 } \\
\text { 国 }\end{array}$ & $\begin{array}{l}\text { 紀 } \\
\text { 伊 } \\
\text { 山 } \\
\text { 地 }\end{array}$ & $\begin{array}{l}\text { 石 } \\
\text { 見 } \\
\text { 銀 } \\
\text { 山 }\end{array}$ & $\begin{array}{l}\text { 合 } \\
\text { 計 }\end{array}$ & & $\begin{array}{l}\text { 全 } \\
\text { 国 } \\
\text { \% }\end{array}$ \\
\hline & \multirow{4}{*}{$\begin{array}{l}\text { 發 } \\
\text { 録 } \\
\text { 資 } \\
\text { 産 }\end{array}$} & 森林 & 3 & 0 & 835 & 14 & 0 & 372 & 370 & 23 & 34 & 342 & 370 & 2363 & 74 & 67 \\
\hline & & 割合 （\%) & 14 & 0 & 85 & 20 & 0 & 89 & 69 & 47 & 60 & 60 & 84 & & - & \\
\hline & & 草原 & 0 & 0 & 19 & 1 & 0 & 4 & 88 & 0 & 1 & 83 & 3 & 200 & 6 & 5 \\
\hline & & 合計 & 21 & 106 & 981 & 71 & 0 & 418 & 537 & 49 & 56 & 494 & 442 & 3176 & 100 & 100 \\
\hline & \multirow{5}{*}{ 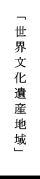 } & 森林 & 253 & 8 & 3595 & 3644 & 0 & 2597 & 1565 & 249 & 210 & 9745 & 2994 & 24860 & 77 & 67 \\
\hline & & 割合 （\%) & 44 & 3 & 77 & 84 & 0 & 85 & 61 & 59 & 33 & 82 & 82 & - & - & - \\
\hline & & 草原 & 1 & 0 & 123 & 189 & 0 & 313 & 121 & 45 & 11 & 863 & 14 & 1681 & 5 & 5 \\
\hline & & 農耕地 & 235 & 59 & 314 & 263 & 11 & 86 & 419 & 46 & 217 & 448 & 447 & 2546 & 8 & 23 \\
\hline & & 市街地その他 & 89 & 194 & 642 & 239 & 29 & 42 & 472 & 82 & 197 & 858 & 213 & 3057 & 10 & 5 \\
\hline
\end{tabular}

\begin{tabular}{|c|c|c|c|c|c|c|c|c|c|c|c|c|c|c|}
\hline \multirow{5}{*}{$\begin{array}{l}\text { (2) } \\
\text { 植 } \\
\text { 林 } \\
\text { 地 }\end{array}$} & \multirow{2}{*}{$\begin{array}{l}\text { 登 } \\
\text { 録 } \\
\text { 㓋 }\end{array}$} & $\begin{array}{c}\text { 植林地以外の森林 } \\
\text { 割合 } \quad \text { (\%) }\end{array}$ & $\begin{array}{r}3 \\
100\end{array}$ & 0 & $\begin{array}{r}408 \\
49 \\
\end{array}$ & $\begin{array}{r}7 \\
47 \\
\end{array}$ & - & $\begin{array}{l}370 \\
100\end{array}$ & $\begin{array}{r}285 \\
77 \\
\end{array}$ & $\begin{array}{l}0 \\
0\end{array}$ & $\begin{array}{r}33 \\
100\end{array}$ & $\begin{array}{r}190 \\
56\end{array}$ & $\begin{array}{r}287 \\
78\end{array}$ & $\begin{array}{r}1584 \\
67 \\
\end{array}$ \\
\hline & & \begin{tabular}{|c} 
植林地 \\
割合
\end{tabular} & $\begin{array}{l}0 \\
0\end{array}$ & 0 & $\begin{array}{r}427 \\
51\end{array}$ & $\begin{array}{r}7 \\
53\end{array}$ & - & $\begin{array}{l}2 \\
0\end{array}$ & $\begin{array}{l}85 \\
23\end{array}$ & $\begin{array}{r}23 \\
100\end{array}$ & $\begin{array}{l}0 \\
0\end{array}$ & $\begin{array}{r}152 \\
44\end{array}$ & $\begin{array}{l}83 \\
22\end{array}$ & $\begin{array}{r}779 \\
33 \\
\end{array}$ \\
\hline & 地世 & $\begin{array}{c}\text { 植林地以外の森林 } \\
\text { 割合 (\%) }\end{array}$ & $\begin{array}{r}229 \\
90\end{array}$ & $\begin{array}{r}8 \\
100\end{array}$ & $\begin{array}{r}2243 \\
62\end{array}$ & $\begin{array}{r}2123 \\
58\end{array}$ & 0 & $\begin{array}{r}2584 \\
100\end{array}$ & $\begin{array}{r}1045 \\
67\end{array}$ & $\begin{array}{l}85 \\
34\end{array}$ & $\begin{array}{l}210 \\
100\end{array}$ & $\begin{array}{r}5297 \\
54\end{array}$ & $\begin{array}{r}2119 \\
71\end{array}$ & $\begin{array}{r}15942 \\
64\end{array}$ \\
\hline & 化 & 植林地 & 24 & 0 & 1352 & 1522 & 0 & 12 & 520 & 165 & 0 & 4447 & 876 & 8918 \\
\hline & 崖 & (\%) & 10 & 0 & 38 & 42 & . & 0 & 33 & 66 & 0 & 46 & 29 & 36 \\
\hline
\end{tabular}

\begin{tabular}{|c|c|c|c|c|c|c|c|c|c|c|c|c|c|}
\hline \multirow{3}{*}{$\begin{array}{l}\text { (3)植生带 } \\
\text { 「世界文化遗 } \\
\text { 産地域」 }\end{array}$} & 亜寒带 - 亜高山帯樹林 & 0 & 0 & 0 & 0 & 0 & 0 & 0 & 0 & 0 & 800 & 0 & 800 \\
\hline & 落葉広葉樹林 & 0 & 0 & 9 & 2008 & 0 & 0 & 0 & 130 & 0 & 4100 & 15 & 6261 \\
\hline & 照葉樹林 & 223 & 8 & 2317 & 304 & & 2895 & 1107 & 0 & 221 & 1083 & 1908 & 10065 \\
\hline
\end{tabular}

※「環境省生物多樣性センター」運営の「生物多様性情報システム」より引用のデータを用いて作成した。

「森林」は7 7 二次林、9 自然林、6植林地の合計値とし、「草原」は 10 自然草原および 4,5 二次草原、「農耕地」は 2,3 農耕地、「市街地その他」は上記以外として 算出した。また、植林地以外の森林は7·8二次林、9自然林の合計、植林地は6植林地の值とした。

表 $-3 \quad$ 森林の位置

\begin{tabular}{|c|c|c|c|c|c|c|c|c|c|}
\hline 分類 & $\begin{array}{l}\text { 法隆寺 } \\
\end{array}$ & $\begin{array}{l}\text { 古都京都 } \\
\end{array}$ & 白川鄉・五箇山 & $\begin{array}{l}\text { 撖島神社 } \\
\end{array}$ & 古都奈良 & 旦光 & $\begin{array}{l}\text { 琉球王国 } \\
\end{array}$ & $\begin{array}{l}\text { 紀伊山地 } \\
\end{array}$ & 石見銀山 \\
\hline A 資産の価値 $=$ 森林 & & & & 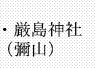 & · 春日山原始林 & & & - 那智原始林 & \\
\hline B 資産の位置=森林 & & $\begin{array}{l}\text { ·驾茂別雷神社 } \\
\text { 酸醐寺* }\end{array}$ & & & & & ·挀場御誉 & 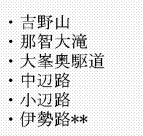 & $\begin{array}{l}\text { ·石見銀山街道 } \\
\text { 䨣石浦道街道 } \\
\text { 温泉澌・沖泊道 }\end{array}$ \\
\hline $\mathrm{C}$ 後背林 & $\begin{array}{l}\text { - 法隆寺 } \\
\text { - 法起寺 }\end{array}$ & 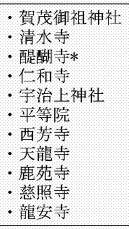 & $\begin{array}{l}\text {. 荻町集落 } \\
\text {. 相合集洛 } \\
\text { · 菅沿集落 }\end{array}$ & $\begin{array}{l}\text { - 辟鳥神社 } \\
\text { (建造物群) }\end{array}$ & $\begin{array}{l}\text { ·平城宮 } \\
\text { ·東大寺 } \\
\text { ·春日大社 }\end{array}$ & $\begin{array}{l}\text { 社二荒山神 } \\
\text { 神束照宫 } \\
\text { ·輪王寺 }\end{array}$ & - 今㷌仁城跡 & 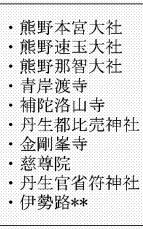 & 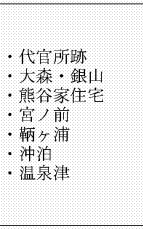 \\
\hline D 資囬 & & $\begin{array}{l}\text { : 延糜寺 } \\
\text { 高山去 }\end{array}$ & & & & - 遗跡 & $\begin{array}{l}\text { - 今帰仁城跡 } \\
\text { ·勝連城跡 } \\
\text { 中中城城跡 }\end{array}$ & 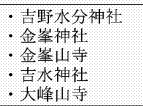 & 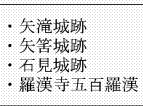 \\
\hline $\begin{array}{c}\text { E その他 } \\
\star \\
\star\end{array}$ & & 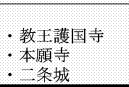 & & & 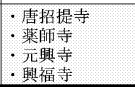 & & 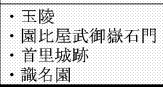 & & \\
\hline
\end{tabular}


表 -4 主な群落名

\begin{tabular}{|c|c|c|c|}
\hline 遺産名 & 群落名 & 面積 (ha) & \begin{tabular}{|c} 
森林面 \\
積に占 \\
めるる割合 \\
$(\%)$ \\
\end{tabular} \\
\hline 法隆寺 & モチツツジーアカマツ群集 & 212.6 & 84.0 \\
\hline \multirow{2}{*}{ 古都京都 } & $\begin{array}{l}\text { アカマツ群落 } \\
\text { 和 }\end{array}$ & 1199.9 & 33.4 \\
\hline & モチツツジーアカマツ群集 & 367.3 & 10.2 \\
\hline 白川郷五箇山 & ブナーミズナラ群落 & 1268.6 & 22.1 \\
\hline 厳島神社 & コバハミツバツツジーアカマツ群集 & 2381.7 & 91.7 \\
\hline \multirow{3}{*}{ 古都奈良 } & モチツツジーアカマツ群集 & 398.2 & 25.5 \\
\hline & サカキーコジイ群集 & 265.9 & 17.0 \\
\hline & クヌギーコナラ群集 & 261.4 & 16.7 \\
\hline 日光 & クリーミズナラ群落 & 84.6 & 33.9 \\
\hline 琉球王国 & ナガミボチョウジークスノハカエデ群落 & 186.1 & 88.5 \\
\hline 紀伊山地 & スズタケーブナ群団 & 3482.9 & 35.7 \\
\hline 石見銀山 & コナラ群落 & 1590.7 & 31.1 \\
\hline
\end{tabular}

「日光」の登録地域は, 東照宮を中心とする約 420 ヘクタール ほどであり, 針葉樹林が分布する男体山などの地域を含まない (図-1 (6)。植林地が多く, 植林地以外はクリーミズナラ群落の 落葉広葉樹林となっている。

「琉球王国」は亜熱帯性のナガミボチョウジークスノハカエデ 群落が約 9 割を占めているが, 座喜味城跡は約 $20 \mathrm{ha}$ のリュウキュ ウマツ群落があり, 斎場御孰には貴重な自生種も見られる ${ }^{25)}$ 。

最も多様な植生区分が見られたのが「紀伊山地」で, 照葉樹林, 落葉広葉樹林，針葉樹林が分布している。植林地以外で最も多かっ たスズタケーブナ群団, 「世界文化遺産地域」で唯一の亜高山針 葉樹林の $160 \mathrm{ha}$ のラビソ - オオシラビソ群集（仏経獄原始林 を含む), コメツガ群落はいずれも大峯奥駆道に分布している。 オオヤマレンゲの自生地を含むこの地区ではシカの被害が拡大し ているという ${ }^{26)}$ 。那智原始林は約 70ha のサカキーコジイ群落に なっているが，周囲を植林地に囲まれており春日山原始林と同じ くその「孤立性」が問題といえる。植林地である吉野山のサクラ は樹勢が衰えてきたため, 奈良県では平成 6 年から対策に取り組 んでいる ${ }^{27)}$ 。また, 熊野速玉大社, 中辺路にはサカキーコジイの 約 $20 \mathrm{ha}$ の群落やモミーシキミ群集がある。

「石見銀山」はコナラ群落が最も多いが，そのほか 170ha の マダケーハチク林, 35ha のモウソウチク林があることが特徴で ある。銀の精錬や坑道には大量の木材を必要とした。坑道にはク リを，精錬にはツバキを燃料にしたとされている ${ }^{28)}$ 。また，登録 資産である銀山柵内では地区の $25 \%$ にあたる約 80 ha が竹林であ る ${ }^{29)}$ 。平成 18 年のデー夕からも八チク林が拡大し, テングス病 の被害が出ていると指摘されている ${ }^{30}$ 。

以上，森林の植生と現状をみると，それぞれの「世界文化遺産 地域」において森林は特に人とのかかわりという点で重要な意味 を持っており, 特徵的な植生も分布していること, 全国の森林同 様, マツ枯れ, 夕ケの繁茂やナラ枯れなどの問題が起こっている
ことが明らかになった。

\section{4. 保護制度}

\section{（1）自然公園及び天然記念物}

世界遺産は各国の制度によって保護が担保されていることが登 録の前提となっているが，文化遺産の登録資産はほとんどが文化 財保護法による文化財として指定又は選定されている。また，バッ ファーゾーンも多くが地方公共団体による条例によって保護が担 保されている。そのうち，自然公園及び天然記念物に関連する指 定は表－5 (1)のとおりである。6 件の文化遺産が自然公園をエリ アに含んでいる。国立公園があるのは「厳島神社」,「日光」,「紀 伊山地」でいずれも特別保護地区が含まれている。また，国定公 園は「古都京都」の琵琶湖国定公園（此嗀山）,「古都奈良」の大 和青垣国定公園（春日山原始林）「紀伊山地」の高野龍神国定公 園（金剛峰寺）があり, 県立自然公園も「紀伊山地」,「白川郷・ 五箇山」にみることができる。登録資産又はバッファーゾーンの 範囲が自然公園で規定されているのは琵琶湖国定公園と五箇山の 県立自然公園である。また，天然記念物は 10 件で，そのうち 4 件は「原始林」として指定されているが，登録資産になっている のはこのうち 3 件のみである。

\section{(2) 国有林}

森林に占める国有林の面積は表－5 (2)の通りである。「㛜島」 はすべてが国有林で，次いで「古都奈良」の登録資産の $65 \%$ 之 なっている。森林面積に占める国有林の割合は登録資産では約 3 割，全体では約 2 割で，全体としては全国平均よりも 1 割ほど低 い值となっている ${ }^{31}$ 。世界自然遺産登録地域では国有林の面積が 95\%である ${ }^{32)}$ のに比較すると国有林の占める割合は著しく低い。

「世界文化遺産地域」で行なわれている活動として,「古事の森」 事業があり，住民団体などと協定を結び，春日山原始林に隣接す る国有林，厳島，高野山などで，林班を設定して植樹や下刈を住 民参加で行なっている ${ }^{33)}$ 。そのほか，京都では銀閣寺山の国有林 の 2 つの林班で「マツ・プロジェクト」として残ったアカマツの 再生を試みている。

\section{5. まとめ}

「世界文化遺産地域」では面積の $77 \%$ を森林が占め, そのう ち 36\%が植林地，20\%が国有林である。また，登録資産の面積 の $74 \%$ が森林であるだけでなく，86\%が位置的な繋がりを持つ。 これらの森林は社寺の後背林, 産業や生活への利用など直接的, 間接的に人との関わりがあり，その結果として二次林や照葉樹林 など, 特徵的な植生が見られる一方, 現在ではナラ枯れなどの被 害が発生している。

以上のことから，「世界文化遺産地域」の保護のためには，た とえば人間との関わりが歴史的に継続している森林については,

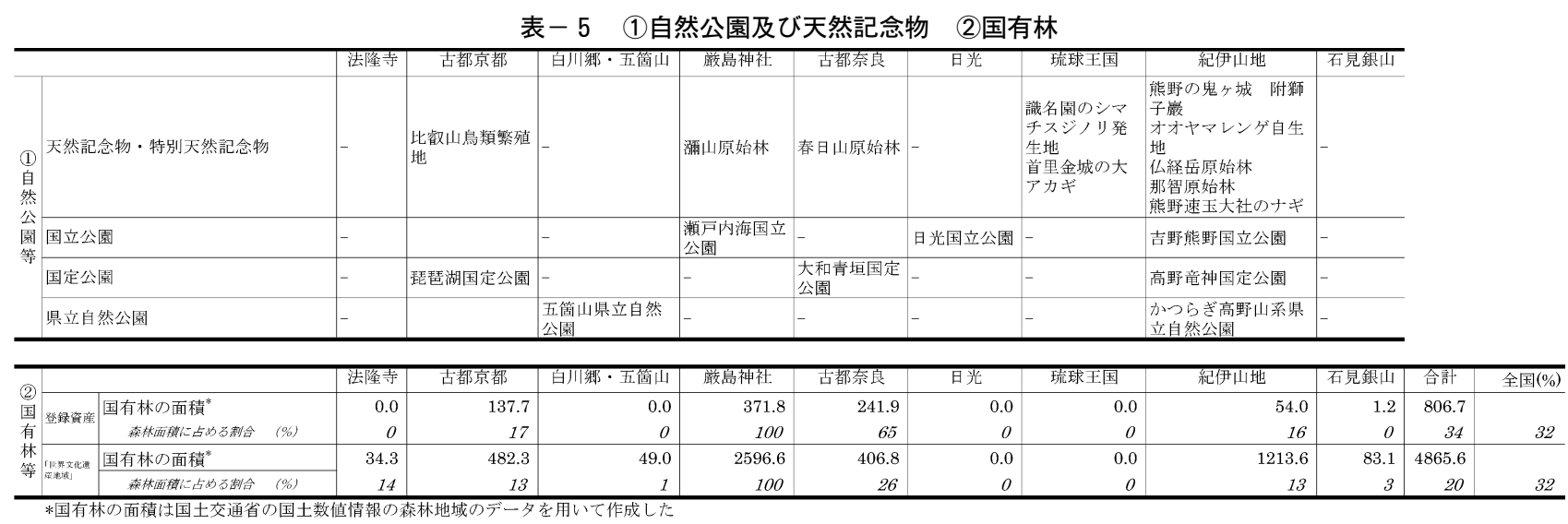




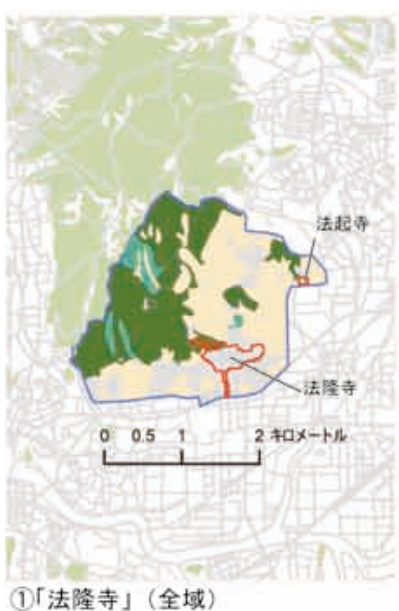

(1)法隆寺」(全域)

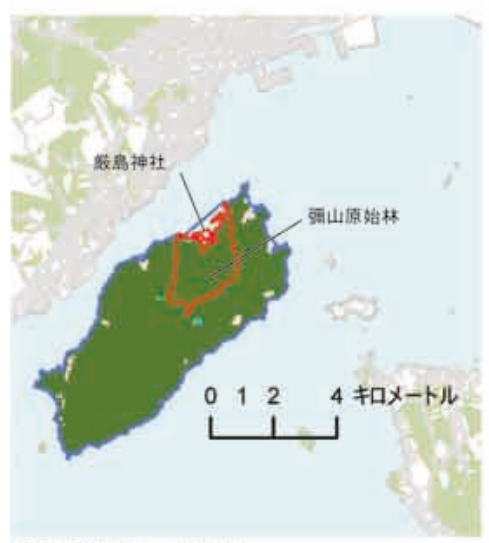

(4)䔕島神社」(全域)

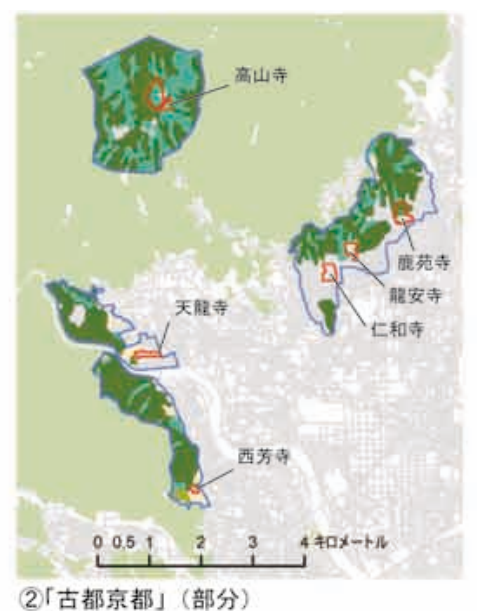

(2)古都京都」(部分)

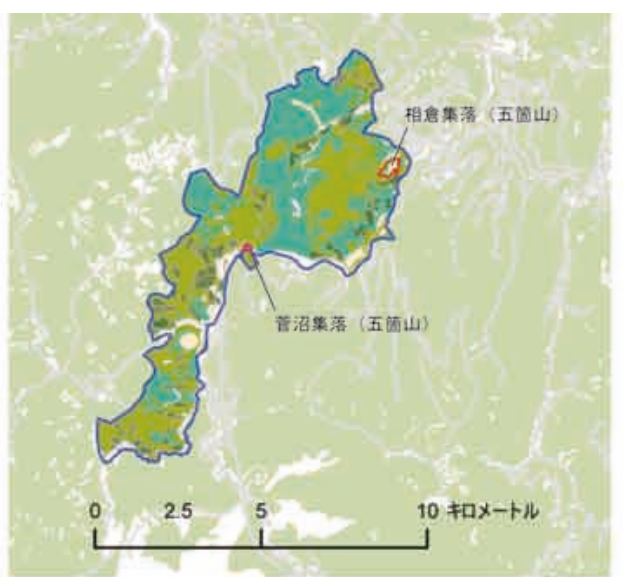

３「白川師・五箇山」(部分)

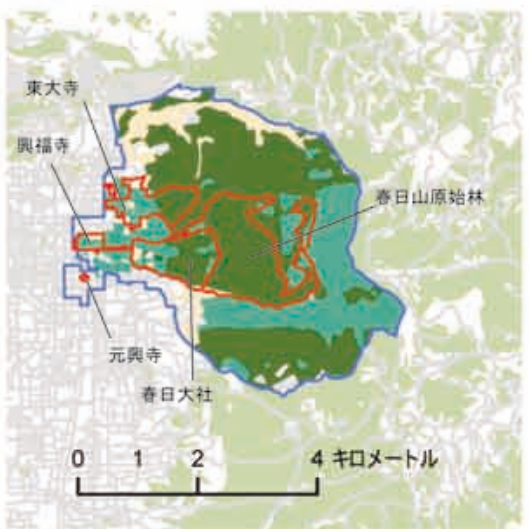

(5)「古都奈良」(部分)

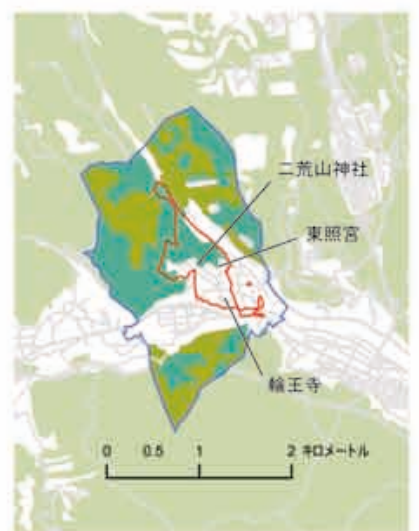

6「日光」(全域)
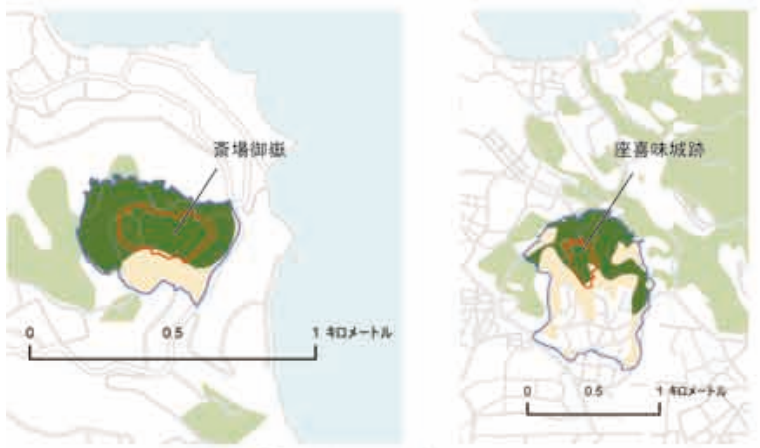

(7)琉球王国」(部分)

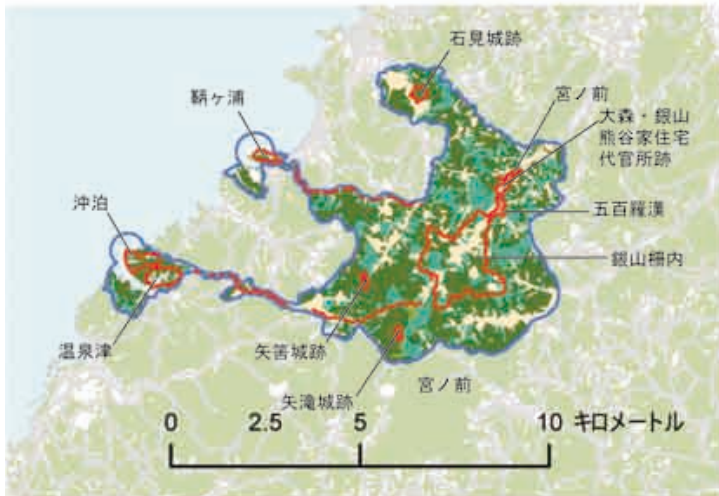

9「石見䥨山」(全域)

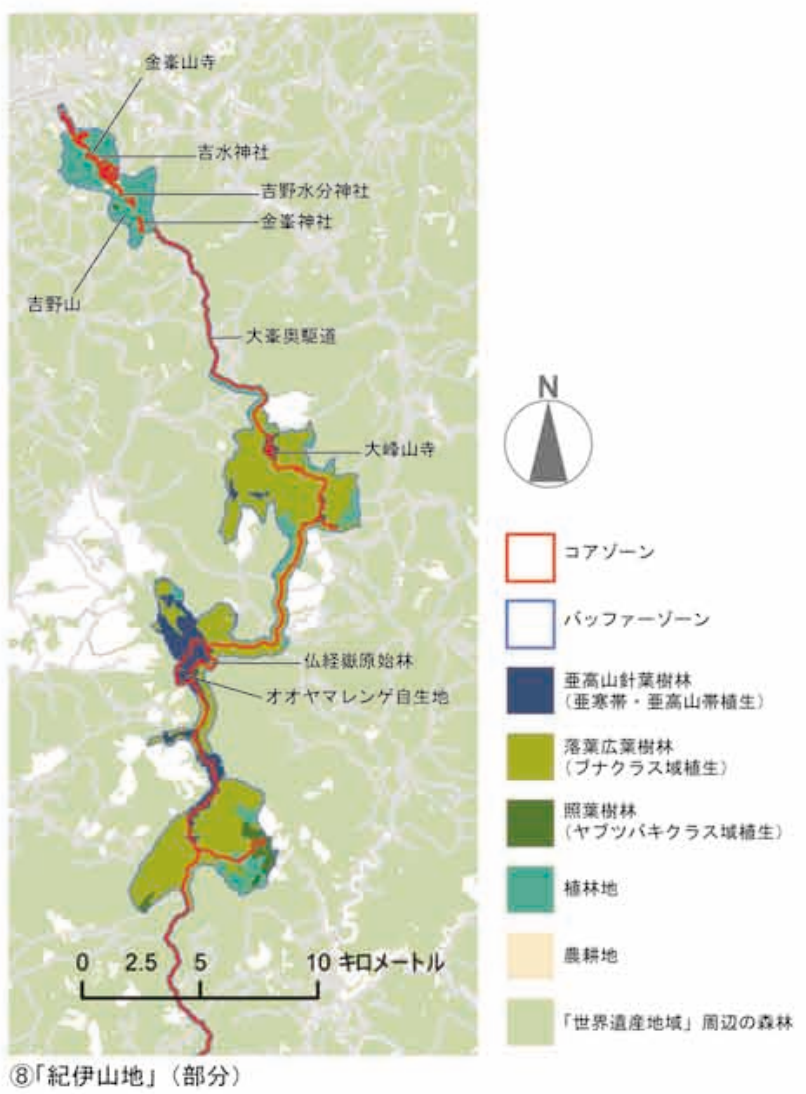


近年の里山保全で行われているように ${ }^{34)}$ ，住民組織や行政が連携 して保護に取り組むこと，また特徵的な植生がみられる登録資産 の後背林では移入植物などのインパクトを軽減する措置が, 人工 林では適切な施業計画の策定が必要であるといえる。「世界文化 遺産地域」に分布するそれぞれの森林の役割を踏まえた施業の方 針を明確にし，世界遺産に義務付けられている保護管理計画（マ ネジメントプラン）に，その施業方針を明記することが必要であ る。そのためには, 都道府県及び市町村において, 自然保護と文 化財保護, 森林整備の部署の連携がより強く求められる。

「世界遺産推薦書」には森林の価值及び管理に関する具体的な 記述は少なく, 文化遺産の価值となっている森林は 3 つの原始林 のみである。今後の推薦資産については, 文化的な評価に加え, 植生も含めた自然的な評価も同時に行なう必要がある。歴史的な 人為の価值が現れている森林の植生は, 文化の価值を客観的に評 価する指標になり, 植生の把握は具体的な森林の保護管理手法の 検討に繋がる。そのためには, 文化庁による文化的な評価だけで はなく, 環境省による種の多様性, 植生の特徴などの評価, 林野 庁も含めた「世界文化遺産地域」の森林管理の検討など, 統合的 な保護施策を実現することが今後の課題である。

\section{謝辞}

本研究は独立行政法人日本学術振興会平成 19 年度及び 20 年度 科学研究費補助金（基盤研究 (C)）「遺産地区における森林の役 割と保全手法一自然遺産と文化遺産保護の融合を目指して一」 （課題番号：19580022）により行われたものである。

\section{補注及び引用文献}

1 ）世界遺産条約を履行するための細則である，世界遺産委員会が定める オペレーショナルガイドライン (The Operational Guidelines for the Implementation of the World Heritage Convention) 第 47 項の定 義による。

2) Adrian Phillips (1995) : Cultural Landscapes: an IUCN Perspect ive : Cultural Landscape of Universal Value : UNESCO, 380-392

3 )「熊野古道，世界遺産登録 1 周年 林業之の両立，課題」（2005 年 7 月 1 日朝日新聞・朝刊）

4）たとえば，補注及び引用文献 13)，14），16），18），19)，20，22)， 23)，28)など

5 ）登録資産及びバッファーゾーンの範囲は，姫路城，原爆ドーム，は 文化庁ホームページ「文化遺産オンライン」<http://bunka.nii.ac. jp/jp/world/h_10.html > (更新日記載なし，2008．7．27参照）掲 載の推萀書, 合掌造り集落世界遺産記念事業実行委員会 (1996)：世 界遗産白川郷 - 五箇山の合掌造り集落, 第 22 回世界遗産委員会支援 京都実行委員会編（1998）：千年の都：世界遺産 古都京都の文化 財 (京都市・宇治市・大津市), 奈良市（1999）：世界遺産古都奈良 の文化財, 日光市教育委員会事務局（2001） : 日光の社寺, 沖縄県教 育庁文化課編（2002）：世界遺産「琉球王国のグスク及び関連遺産群」, 世界遺産登録推進三県協議会 (2005) : 世界遗産紀伊山地の霊場之参 詣道, 島根県教育庁文化財課世界遺産登録推進室編（2005）：石見銀 山の図版を，厳島神社及び法隆寺は推薦書のコピーを用いた。

6 ）「環境省生物多様性センター」運営の「生物多様性情報システム」ホー ムページ<http://www.biodic.go.jp/kiso/gisddl/gisddl_f.html>, (更新日記載なし, 2008.7.27 参照) の植生調查（第 $2-5$ 回植生調查 重㸚わせ植生）を使用した。

7）国土数值情報ホームページ<http://nlftp.mlit.go.jp/ksj/jpgis/jpgi s_datalist.html > (更新日記載なし, 2008.7.27 参照) の森林地域の デー夕を使用した。

8 ）前掲注 5 ）の「世界遺産推薦書」の資料の図から作成した。

9 ）登録資産の「歴史」に関する記述の一部であるが, 文脈上は「文化 的景観」における人工林の有用性の説明と考えられ，必ずしも「林業 が基幹産業でなければ，都市化が進み深い森林は残らなかった」とい う事実を示すものではない。

10）算出した遺産地区の面積は文化庁が発表している面積と異なる部分も
あるが, 発表の面積は実際のものと異なるものもあるため, 本研究で は推薦書を基に GIS で算出した結果を用いた。

11）前揭注 4 のデー夕を用いて作成した。

「森林」は 7 ・8 二次林, 9 自然林, 6 植林地の合計値とし, 「草原」 は 10 自然草原及び 4,5 二次草原, 「農耕地」は 2,3 農耕地, 「市街地そ の他」は上記以外として算出した。また，植林地以外の森林は $7 \cdot 8$ 二次林，9 自然林の合計，植林地は 6 植林地の值とした。

12）GIS 上のデータで分類した後，航空写真（"Google Earth"， (c) 2008 Google,(c) 2008Terra Metrics, (c)2008 Europe Technologies, (c) 2008 ZENRIN)，(2008.9.9 参照)で確認した。

13）中嶋節子（1994）：昭和初期における京都の景観保全思想と森林施業： 日本建築学会計画系論文集 459, 185-193, 同（1996）：明治初期加 ら中期にかけての京都の森林管理と景観保全：日本建築学会計画系論 文集 481, 213-222

14）森下和路・安藤信（2002）：京都市市街地北部森林のマツ枯れに伴う 森林変化: 森林研究 74 , 京都大学大学院農学研究科附属演習林, 3545

15）京都森林管理事務所ヒアリングより（2008.7.11）

16）湯本貴和・松田裕之編（2006）：世界遺産をシカが喰う：文一総合出 版, 148

17）前揭注 16,147

18）前迫ゆり（2005）：春日山原始林：植物群落モニタリングのすすめ： （財）日本自然保護協会編，119-124

19）合田昭二・有本信昭編（2004）：白川郷一世界遺産の持続的保全への 道一: ナカニシヤ出版, 40-44

20）和田尚子・鈴木雅和・横張真（2007）：五筒山相倉集落における茅茸 き屋根維持システムに関する研究：ランドスケープ研究 70(5)，689694，黒田乃生（2002）：白川村荻町の森林における利用と景観の変 容に関する研究：ランドスケープ研究 65(5), 659-664

21）独立行政法人森林総合研究所関西支所（2007）：ナラ枯れの被害をど う減らすか一里山林を守るために一，3，及び 2008 年 8 月の目視調查 による。

22）例えば，乾環・本田正次（1930）：厳島彌山原始林調查報告書：天然 紀念物調查報告植物之部第十輯：文部省, 25-28, 堀川芳雄（1942）： 厳島の植物：廣島縣史蹟名勝天然紀念物調查報告第五輯：広島県, 15 7-212，鈴木兵二ら（1975）：厳島（宮島）の森林植生：厳島の自然 総合学術研究報告 : 宮島町, 133-152，などがある。

23）豊原源太郎・鈴木兵二（1975）：厳島（宮島）と本土とのアカマツ林 の比較研究 : 厳島の自然 総合学術研究報告 : 宮島町, 119-131

24）広島大学大学院理学研究科附属宮島自然 植物実験所編 (2007)：宮島 の植物之自然（配布版）

25）「自然環境の保全に関する指針沖縄島編（陸域）」沖縄県ホームペー シ <http://www.pref.okinawa.jp/okinawa_kankyo/shizen_hogo/ hozen chiiki/shishin/okinawatou hozen shishin/okinawatou riku_shizen2.html> (更新日記載なし, 2008.9.5 参照)

26）前掲注 16，105-146

27）奈良県自然環境課ホームページ<http://www.pref.nara.jp/dd aspx_menuid-5299.htm>（2008.8.27 更新，2008.9.9 参照）

28）仲野義文（2007）：石見銀山とたたら製鉄を支えた里山の環境歴史学： 第 15 回全国雑木林会議石見銀山大会報告書 : 第 15 回全国雑木林会議 石見銀山大会実行委員会, 9-25

29）平成 18 年度撮影の航空写真を基に作成されたデータでも約 $25 \%$ の竹 林があるとされている。（井上雅仁（2007）：石見銀山の森林の現状 之課題：第 15 回全国雑木林会議石見銀山大会報告書 : 第 15 回全国雑 木林会議石見銀山大会実行委員会，26）

30) 前掲注 29

31）林野庁ホームページ，平成 17 年度森林・林業白書 $<$ http://www.rinya.maff.go.jp/seisaku/sesakusyoukai/ 17hakusyo/5syou.html>（更新日記載なし，2008.9.7 参照）

32）前掲注 31 (2008.9.7 参照)

33）近畿中国森林管理局（2008.7.9），奈良森林管理事務所（2008.7.10）, 及び京都森林管理事務所（2008.7.11）へのヒアリングによる。

34）環境省（2008）：里地里山保全再生計画作成の手引き，環境省ホーム ページ，里地里山保全再生の取組の事例 <http://www.env.go.jp/na ture/satoyama/jirei.html > (更新日記載なし，2008.11.28 参照） 